\section{Prof. A. M. Hocart}

WE regret to record the death of Prof. A. M. Hocart, professor of social anthropology in the University of Cairo, which took place on March 9 at the age of fifty-five years.

Arthur Maurice Hocart was born in Guernsey, and entered Exeter College, Oxford, as an open scholar in classics in 1902. On taking his degree he was elected to a senior studentship of Exeter College and afterwards of Jesus College, where he devoted himself to the study of anthropology. He afterwards joined an anthropological expedition to the Solomon Islands organized by the late Dr. W. H. R. Rivers, with whom he contracted a close friendship, and by whom the subsequent trend of his studies was strongly influenced. After a period of travel and research in Melanesia, Hocart accepted a Government post as inspector of schools on the appointment of Sir Everard im Thurn, then Governor of the Western Pacific, and during the residence in Fiji entailed by his duties he engaged in anthropological observation among the Fijians, collecting much material on the traditions, social organization and beliefs of the people, which he utilized to good purpose in his later writings. Its influence is especially apparent in his book on "Kingship" (1927).

In 1921, Hocart was appointed director of the Archæological Department in the island of Ceylon, and the influence of his energy, scholarship and enthusiasm for his subject soon made itself apparent in an increased and extended activity in his department's survey of the ancient monumental remains of the island, as well as in the standard, character and range of its publications.

Hocart's health, never robust, and showing traces of the effects of his residence in the Pacific, led to the resignation of his post in Ceylon, and in 1929 he returned to England, where for a period he acted as librarian of the Royal Anthropological Institute. In 1934 he succeeded Dr. E. E. Evans-Pritchard in the chair in the University of Cairo, which he occupied until his death.

Hocart's work in Melanesia had provided him with a wealth of ethnographical material which he was engaged in digesting over a considerable period of years and of which he published selections from time to time in the Journal of the Royal Anthropological Institute and other publications of a more or less technical character. His books were of a more general and theoretical outlook. In "The Progress of Man" (1933) he made a general survey of the subject-matter of anthropological science. It is both sound and original, while salted with a humour which at times was biting. In 1936 his "Kings and Councillors" was published in Cairo.

Hocart in outlook and method was a diffusionist in the sense that he followed Rivers in making use of precise cultural analysis in tracing the history of cultural and ethnic distributions; but in applying this method to general anthropological problems, his meticulous sense of scholarship deprecated any loose generalization based upon vague analogy, avoiding it in his own work and criticizing it sharply in others.

\section{Sir Basil Thomson, K.C.B.}

THE sudden death of Sir Basil Thomson, formerly assistant commissioner of the Metropolitan Police and director of intelligence at Scotland Yard, which took place on March 26 at the age of seventyeight years, brings to a close a career no less remarkable for the versatility it displayed than for its actual achievement. Its interest for the anthropologist lies in the fact that as a colonial officer, Thomson was an outstanding example, among members of the old school of administrators, of those who, while without special training in anthropology, attained efficiency in their methods of administration in dealing with native affairs by acquiring and applying a sympathetic knowledge and understanding of native institutions and ways of thought.

Basil Home Thomson, son of William Thomson, Archbishop of York, was born on April 21, 1861, and educated at Eton and New College, Oxford. $\mathrm{He}$ entered the Civil Service and served for ten years in Fiji, Tonga and New Guinea. In 1900, after he had retired from the Colonial Service for some years, he returned for a period to the Pacific, being seconded under the Colonial Office as a special commissioner to negotiate treaties with two of the native Governments.

Among 'Thomson's numerous works, the writings of his earlier years are of more than passing interest to the anthropologist. $\mathrm{He}_{e}$ was an accurate and systematic observer, with insight into the characters and ways of thought of the peoples with whom he had to deal. His books, describing conditions which have now passed away, have a permanent value as records. In "The Diversions of a Prime Minister" (1894) he describes with no little humour the remarkable condition of affairs which he encountered as prime minister of Tonga, when he succeeded the notorious Shirley Baker. This was followed by "Discovery of the Solomon Islands" (1901) and "Savage Island" (1902), and "Fiji and the Fijians" (1908), now a standard book, which commands a rising price in the market. He also contributed papers to the Journal of the Anthropological Institute, of which one is a careful description of the remarkable stone trilithons of Tongatabu.

\section{WE regret to announce the following deaths :}

Sir William Butler, president of the Institute of Brewing in 1906, who was connected with the School of Brewing in the University of Birmingham for many years, on April 5, aged seventy-two years.

Prof. J. W. Edington, professor of bacteriology in the University of Sheffield, known for his researches on diphtheria, on April 8, aged fifty-four years.

Prof. W. E. Ford, professor of mineralogy in Yale University since 1920, on March 23, aged sixtyone years.

Prof. G. Hellmann, professor of meteorology in the University of Berlin.

Dr. W. H. Park, emeritus director of the Bureau of Laboratories of the New York City Health Department, known for his work on combating diphtheria and other diseases, on April 5, aged seventy-five years. 